\title{
IMPROVING STUDENTS' MOTIVATION OF LEARNING USING BLENDED LEARNING STRATEGY FACILITATED WITH VARK LEARNING STYLE MODEL
}

\section{MENINGKATKAN MOTIVASI BELAJAR SISWA MENGGUNAKAN STRATEGI BLENDED LEARNING DIFASILITASI GAYA BELAJAR VARK}

\author{
By: \\ Yessica Mega Aprita \\ Accounting Education Department \\ e-mail : yess_cha@yahoo.com \\ Annisa Ratna Sari \\ Lecturer Accounting Education Department Yogyakarta State University
}

\begin{abstract}
The type of this research is Classroom Action Research aimed to improve students' Motivation of Learning of Grade X AK 1 SMK Negeri 1 Bantul Academic Year of 2013/2014.

The research is done in two cycles uses two kinds of data collection techniques, i.e. observation and questionnaire. The data collected was analyzed by qualitative analysis using three steps, data reduction, data presentation and conclusion formulation. The analysis is completed with descriptive quantitative analysis to calculate the score of Accounting Learning Motivation.

Based on the research result, the implementation of Blended Learning Strategy facilitated with VARK Learning Style Model is able to improve students' Accounting Motivation of Learning of the grade X AK 1 SMK Negeri 1 Bantl accounting academic year of 2013/2014. It is proven by the improvements of X AK 1's average score of Learning Motivation from $76,71 \%$ on the first cycle and reaches to $84,18 \%$ on the implementation of the second cycle. This improvement shows that using Blended Learning Strategy facilitated with VARK Learning Style Model, the students' Motivation of Learning is increasing classically, without any domination from a few of students of the class.
\end{abstract}

Keywords: blended learning, VARK learning style model, motivation, motivation of learning

\section{ABSTRAK}

Penelitian ini merupakan Penelitian Tindakan Kelas yang bertujuan untuk meningkatkan Motivasi Belajar siswa kelas X AK 1 SMK Negeri 1 Bantul tahun pelajaran 2013/2014.

Penelitian ini dilakukan dalam dua siklus dengan menggunakan dua metode pengumpulan data yaitu observasi dan angket dimana data yang terkumpul kemudian dianalisis dengan analisis data kualitatif melalui tiga tahap, yaitu reduksi data, penyajian data dan penarikan kesimpulan. Analisis kualitatif tersebut kemudian dilengkapi dengan analisis statistic deskriptif untuk menghitung skor Motivasi Belajar Akuntansi.

Berdasarkan hasil penelitian disimpulkan bahwa implementasi Strategi Blended Learning dengan Gaya Belajar VARK dapat meningkatkan Motivasi Belajar Siswa Kelas X 
AK 1 SMK Negeri 1 Bantul Tahun Pelajaran 2013/2014 dibuktikan dengan adanya peningkatan skor Motivasi Belajar kelas X AK 1 dari 76,71\% pada siklus pertama dan mencapai 84,18\% pada siklus kedua. Peningkatan ini menunjukkan bahwa Strategi Blended Learning dengan Gaya Belajar VARK mampu meningkatkan Motivasi Belajar siswa kelas X AK 1 SMK Negeri 1 Bantul secara klasikal tanpa dominasi dari beberapa siswa saja.

Kata Kunci : blended learning, gaya belajar VARK, motivasi, motivasi belajar

\section{A. Introduction}

Education is a systematic process through which a child or an adult acquires knowledge, experience, skill and sound attitude. It makes an individual be more civilized, refined, cultured and educated. For a civilized and socialized society, education is the only means. Its goal is to shape a reliably citizen. This is consistent with the meaning of education by UU No. 20 Tahun 2003 about the National Education System, in $1^{\text {st }}$ section:

Pendidikan adalah usaha sadar yang terencana untuk mewujudkan suasana belajar dan proses pembelajaran agar peserta didik secara aktif mengembangkan potensi dirinya untuk memiliki kekuatan spiritual keagamaan, pengendalian diri, kepribadian, kecerdasan, akhlak mulia, serta keterampilan yang diperlukan dirinya, masyarakat, bangsa dan negara.

Align with the definition above, the purpose of National Education in Indonesia as also stated in $U U$ No. 20 Tahun 2003 is:

"berkembangnya potensi peserta didik agar menjadi manusia yang beriman dan bertakwa kepada Tuhan Yang Maha Esa, berakhlak mulia, sehat, berilmu, cakap, kreatif, mandiri, dan menjadi warga negara yang demokratis serta bertanggung jawab".

By possesing knowledge, creativity and autonomy, the students will be able to actively involved in the society.

Basically human is born as a learner. The duties and responsibilities of a man is to be a learner. Learning is not only a process of absorbing knowledge from the teacher, but learning is also a process in which students are required to actively involved in learning activities.

The developments in information and communications technology offers flexibility for education. Blended learning, for example, is a learning strategy that integrates technology and information-based learning with classroom-based learning / face to face. Blended learning has several advantages, such as: have the various learning approaches, easier to access the knowledge, social interaction, save costs, and easier to make a revision. Blended learning allows the students to convergence the different methods, learning resources media, and other relevant learning environments based on their own learning style and their own desire. (Young, 2002)

In accounting learning, students should learn on their own desire and on their own learning style, so the concept of learning can be well understood. Therefore it takes students' motivation to develop each potential to study accounting.

During their study, students usually have various learning styles and these can affect how they learn. Learning 
styles is a term used to refer to the methods of gathering, processing, interpreting, organizing, and thinking about information. Students have different learning styles, which shows up in the classroom in the different ways that students acquire information. (Miller, 2001)

There are numerous learning style inventories available, but this research specifically examines an intervention using the VARK inventory. The VARK inventory gathers information according to an instructional preferences model (Fleming, 1998).

Based on the observations in the grade X AK 1 SMK N 1 Bantul, known that the students' learning motivation is still low. This problem is reflected from the students' activities that reflect the low Motivation of learning during the Accounting learning process. When doing the exercise from the teacher, $37,88 \%$ students did not finish it at all. If they met difficulties, $36,33 \%$ students did not ask what they did not understand either to the teacher or a friend. Besides, in enrolling the class, $36,36 \%$ students sometimes pay their attention to the teacher and chatting outside material. Then, there are $36,36 \%$ students who were cheating or waiting for their friends' answer in doing the examination. Additionally, when they have to do the routine tasks, $33,48 \%$ students procrastinate in doing that task and even were not did the task. When students are given the questions from the teacher, about $32,58 \%$ students cannot give any answer. Then, in the discussion method, $35,61 \%$ of students were not sure and were easily let go of their opinion. Finally, in their spare time, 36,36\% students were not try to find and troubleshoot the accounting exercises, they prefer to play their cellphone.

Too much intensity of lecturing and drill (give a lot of exercise) is also found in the teaching method in Grade X AK 1 SMK Negeri 1 Bantul. The use of monotonous teaching method made the students feel bored. The structure of Accounting learning material that tend to be more calculating makes the narrow point of teacher that explaining Accounting is will be suitable with the lecturing and drilling method. The students were just keep silent and listen to their teacher's explanation. This condition makes the Accounting learning process less interesting, less challenging, and meaningless for the students, so the learning process can not wake the students' motivation of learning up yet.

Based on the background of the study above, it proposed a research entitled "The Implementation of Blended Learning Strategy Facilitated With VARK Learning Styles Model To Improve Students' Motivation of Learning: Case Study Of Grade X AK 1 SMK N 1 Bantul Academic Year Of 2013/2014".

\section{B. Research Method}

1. Research Type

The type of this research is Classroom Action Research (CAR) conducted collaboratively so the researchers did not conduct its own research, however, collaborate or cooperate with the accounting teacher and participatory, the researchers directly involved in the implementation of research step by step. The research was conducted in the classroom in order to improve or increase learning motivation of the students in accounting subjects. Aqib Zainal, et al (2009: 3) stated that "Penelitian tindakan kelas (PTK) adalah penelitian yang dilakukan oleh guru di kelasnya sendiri melalui refleksi diri dengan tujuannya untuk memperbaiki kinerjanya sehingga hasil belajar siswa meningkat". 


\section{Research Subject and Object}

The subject of this research is 33 students of $\mathrm{X}$ AK 1 at SMK Negeri 1 Bantul, while the object of the research is students' learning motivation using blended learning strategy facilitated with VARK learning styles model.

\section{Research Instruments}

According to Suharsimi Arikunto (2006:160), "The research instrument is a tool or facility that is used by researchers in collecting data in order to work more easily and better results, in terms of more accurate, complete and systematic, so it will easy to be processed". The instrument used in this study is in the form of observation sheets, questionnaires sheet and field notes. In the preparation of this questionnaire using Likert Scale, with two alternative statements, positive and negative statements.

Table 1. The Framework of Learning Motivation Instruments
\begin{tabular}{|l|l|l|c|}
\hline \multicolumn{1}{|c|}{ Variables } & \multicolumn{1}{|c|}{ Item } & Total \\
\hline Motivations & 1. Diligent in doing the tasks & $1,2^{*}, 3$ & 3 \\
& 2. Not easily discouraged & $4^{*}, 5,6,7^{*}$ & 4 \\
& 3. Showed enthusiasm in enrolling & $8,9,10$ & 4 \\
& $\quad$ the class & & \\
& 4. Prefer to work independently & $11,12^{*}, 13$ & 3 \\
& 5. Quickly bored with routine tasks & $14^{*}, 15,16$ & 3 \\
& 6. Can maintain his opinion & $17,18^{*}$ & 2 \\
& 7. Not easy to let go of their beliefs & $19^{*}$ & 1 \\
& 8. Like to locate and troubleshoot & 20 & 1 \\
\hline problems & & \\
\hline Total & & & 24 \\
\hline
\end{tabular}

\section{Data Analysis Technique}

The research uses Qualitative Research Techniques to analyze the data collected from field note in form of description, researcher uses Qualitative Research Technique developed by Miles Huberman (Sugiyono,2009:246253) that consist of three techniques, they are:

\section{a. Data Reduction}

The reduction is done by selecting, focusing and abstracting raw data in to the simpler and more meaningful data. The data which is relevant each others are reduced to the more focus and meaningful data to earn beneficial information.

\section{b. Data Presentation}

After being reduced, the data is organized and described in a form of descriptions, tables, graphics, matrix, etc.

\section{c. Conclusion Formulation}

Conclusion formulation is the last step of data analysis. Formulating conclusion aims to earn the main point of the data in a form of explicit sentences.

For the data collected by observation and questionnaire, researcher is going to uses Descriptive Analysis which means simple mathematical function to manage the data by converting data in to numerical and simple data (Metler, 2011:261). The data collected from observation and questionnaire analyzed by giving learning motivation score from 1 to 4 .

Table 2. Scoring Rubric
\begin{tabular}{|l|c|l|c|}
\hline \multicolumn{2}{|c|}{ Positive Statement } & \multicolumn{2}{c|}{ Negative Statement } \\
\hline $\begin{array}{c}\text { Altemative } \\
\text { Statement }\end{array}$ & Score & $\begin{array}{c}\text { Altemative } \\
\text { Statement }\end{array}$ & Score \\
\hline Always & 4 & Always & 1 \\
\hline Often & 3 & Often & 2 \\
\hline Seldom & 2 & Seldom & 3 \\
\hline Never & 1 & Never & 4 \\
\hline
\end{tabular}

According to the score, researcher calculates the percentage of students' learning motivation and interprets the percentage in a form of description. The analysis involves three steps, they are:

1) Determine the procedures in giving score for each indicator of learning motivation.

2) Calculate the score for each indicator.

3) Calculate the Learning Motivation score by the formulas:

$$
\%=\frac{\text { Score of Leaming Motivation }}{\text { Maximum Score }} \times 100 \%
$$

(Sugiyono, 2009:137) 


\section{Research Result and Discussion}

From research conducted which includes initial thoughts, reconnaisance, overall plan, action, as well as monitoring and reconnaisance have been obtained the data as aforesaid. In the implementation of Blended Learning strategy facilitated with VARK learning style, both on cycle 1 and cycle 2 , the students showed the activities that shows their motivation to learn. For more details presented the data about students' motivation of learning on cycle 1 and cycle 2:

Table 3. Comparison of Students' Motivation of Leaming on Pre Research,
Cycle 1 And Cycle 2 Score
\begin{tabular}{|l|c|c|c|c|}
\hline \multicolumn{1}{|c}{ Indicators } & \multicolumn{3}{|c|}{ Score (\%) } & $\begin{array}{c}\text { Improvement } \\
(\%)\end{array}$ \\
\cline { 2 - 5 } & Pre $^{*}$ & Cycle 1 & Cycle 2 & $\mathbf{1 - 2}$ \\
\hline Diligent in doing the tasks & 62,12 & 76,52 & 84,09 & 7,57 \\
\hline Not easily discouraged & 66,67 & 75,76 & 86,36 & 10,6 \\
\hline $\begin{array}{l}\text { Showed enthusiasm in } \\
\text { enrolling the class }\end{array}$ & 63,64 & 78,03 & 81,06 & 3,03 \\
\hline $\begin{array}{l}\text { Prefer to work } \\
\text { independently }\end{array}$ & 63,64 & 78,03 & 80,30 & 2,27 \\
\hline $\begin{array}{l}\text { Quickly bored with } \\
\text { routine tasks }\end{array}$ & 76,52 & 87,12 & 92,42 & 5,3 \\
\hline Can maintain his opinion & 67,42 & 71,97 & 83,33 & 11,36 \\
\hline $\begin{array}{l}\text { Not easy to let go of his } \\
\text { belief }\end{array}$ & 64,39 & 68,94 & 84,09 & 15,15 \\
\hline $\begin{array}{l}\text { Likes to locate and } \\
\text { troubleshoot problems }\end{array}$ & 63,64 & 77,27 & 81,82 & 4,55 \\
\hline Average Score & 66,01 & 76,71 & 84,18 & 7,47 \\
\hline
\end{tabular}
Source: Primary Data Processed
Notes: Pre Research Data

Based on the data above, it can be seen that there is an increase of cycle 1 to cycle 2 score for $7,47 \%$. Hence, it has been proven that by the implementation of Blended Learning strategy facilitated with VARK learning style model is able to improve the students'motivation of learning on the basic competence of arranging adjusting journal entries and preparing the balance sheet of the student of Grade X AK1 SMK Negeri 1 Bantul Academic Year of 2013 / 2014.

\section{Conclusion}

Based on the research result and discussion, the implementation of Blended Learning Strategy facilitated with VARK Learning Style Model is able to improve students' motivation of learning in SMK Negeri 1 Bantul. The judgement is proven by the increase in the percentage score of motivation of learning that taken through the observation, and the observation sheet shows the score of $66,01 \%$ before the implementation of blended learning strategy facilitated with VARK learning style model then rose to $76,71 \%$ in cycle 1 or can be said increasing by $10,7 \%$ from the pre research up to the cycle 1 . Next on cycle 2 also occur an increase of $7.47 \%$ or obtained a score of $84,18 \%$.

\section{E. References}

Arikunto, Suharsimi. (2006). Prosedur Penelitian : Suatu Pendekatan Praktek. Jakarta: Rineka Cipta.

Dimyati \& Mudjiono. (2009). Belajar dan Pembelajaran. Jakarta: PT. Rineka Cipta.

Hamzah. (2008). Teori Motivasi dan Pengukurannya: Analisis di Bidang Pendidikan. Jakarta: Bumi Aksara.

Isjoni \& Mohd Arif Ismail. (2008). Model-model Pembelajaran Mutakhir Perpaduan Indonesia Malaysia. Yogyakarta: Pustaka Belajar.

Iskandar. (2009). Psikologi Pendidikan: Sebuah Orientasi Baru. Jakarta: Gaung Persada.

Lindy Peterson. (2008). Bagaimana Memotivasi Anak Belajar: Stop and Think Learning. Jakarta: PT. Grasindo.

Mulyasa. (2009). Menjadi Guru Profesional: Menciptakan Pembelajaran Kreatif dan Menyenangkan. Bandung: PT. Remaja Rosdakarya. 
Purwanto, Ngalim. (2007). Psikologi Pendidikan. Bandung: PT. Remaja Rosdakarya.

Pusat Bahasa Departemen Pendidikan Nasional. (2008). Kamus Besar Bahasa Indonesia. Jakarta: PT. Gramedia Pustaka Utama.

Reid, Gavin. (2008). Model Pembelajaran : Menciptakan Proses Belajar Mengajar yang Kreatif dan Efektif. Jakarta : Bumi Aksara.

Republik Indonesia. (2005). UndangUndang Nomor 20 Tahun 2003 Tentang Sistem Pendidikan Nasional. Jakarta : Sinar Grafika.

Rusman. (2011). Model-Model Pembelajaran: Mengembangkan Profesionalisme Guru. Jakarta: PT. Raja Grafindo Persada.

Sanjaya, Wina. (2008). Strategi Pembelajaran Berorientasi Standar Proses Pendidikan. Jakarta : Kencana.

Sardiman. (2011). Interaksi dan Motivasi Belajar Mengajar. Jakarta: PT. Raja Grafindo Persada.

Somantri, Hendi. (2005). Memahami Akuntansi SMK Seri B. Bandung: Armico

Sucipto, Toto. 2009. Akuntansi 2 untuk SMK Kelas XI. Jakarta : Yudhistira.

Sugihartono. et. al. (2007). Psikologi Pendidikan. Yogyakarta: UNY Press.

Sugiyono. (2010). Metode Penelitian Pendidikan. Bandung: CVAlfabeta.

Syah, Muhibbin. (2011). Psikologi Belajar. Jakarta: CV Alfabeta.
Wiriatmadja, Rochiati. (2009). Metode Penelitian Tindakan Kelas untuk Meningkatkan Kinerja Guru dan Dosen. Bandung: PT. Remaja Rosdakarya.

Zainal, Aqib. 2009. Penelitian Tindakan Kelas. Bandung: Yrama Widya. 